Review

\title{
Surface modification of spray dried food and emulsion powders with surface-active proteins: A review
}

\author{
M. Jayasundera, B. Adhikari *, P. Aldred, A. Ghandi \\ School of Science and Engineering, University of Ballarat, Mount Helen, VIC 3350, Australia
}

\section{A R T I C L E I N F O}

Article history:

Received 25 July 2008

Received in revised form 30 January 2009

Accepted 31 January 2009

\section{Keywords:}

Sugar-rich foods

Stickiness

Proteins

Surfactants

Emulsions

Spray drying

\section{Contents}

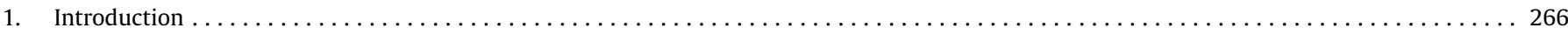

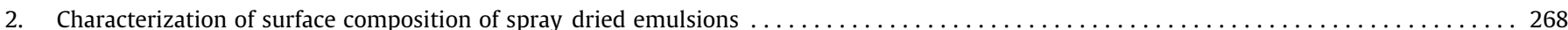

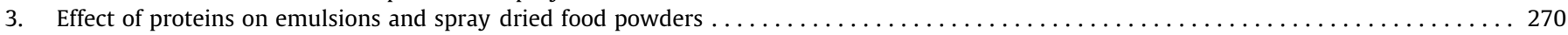

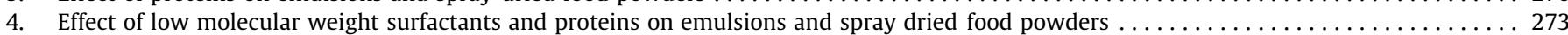

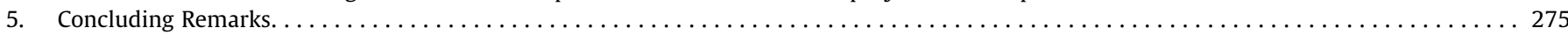

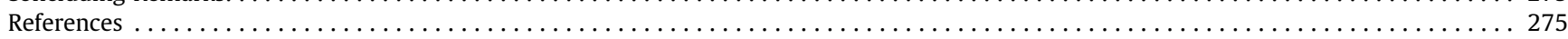

\section{Introduction}

There are many food products that have very high sugar and organic acid contents and there is a growing interest to convert them into more useable and stable forms such as powders (Bhandari et al., 1997). Conversion of high value food materials such as fruit and vegetable extracts and honey into particulate form is not easy due the presence of a high proportion of low molecular weight sugars in their composition (Adhikari et al., 2007a). This results in low glass temperature $\left(T_{g}\right)$, which is attributed to be the main reason for stickiness (Vega et al., 2005a). Many foods are amorphous or crystalline or a mixture of both depending on the composition of materials and the pro cessing technology used (Boonyai, 2005). Crystals are formed by

\footnotetext{
* Corresponding author. Tel.: +61 3 53279249; fax: +61 353279240 .

E-mail address: b.adhikari@ballarat.edu.au (B. Adhikari).
}

crystallization of dissolved solids by concentration or cooling the solution to achieve super saturation. Crystalline powders are less hygroscopic and therefore, more stable to physical and chemical degradation compared to other forms. Amorphous powders are formed by rapidly removing the dissolving/dispersing medium and rapid cooling of a melt or super cooling of aqueous solution; these processes do not allow crystallization to take place (Fig. 1). The amorphous form is a non equilibrium meta stable state of materials (Alexander and King, 1985). Table 1 summarizes experimental conditions that have been most frequently used for the encapsulation of different food ingredients through spray drying.

Low molecular weight sugars, such as fructose, glucose, su crose and lactose in the amorphous state have high hygroscopic ity and solubility. Crystalline sugars may contain an amorphous fraction due to milling and size reduction operations (Kelley et al., 1974; Bhandhari and Howes, 2004). In food, the physical 


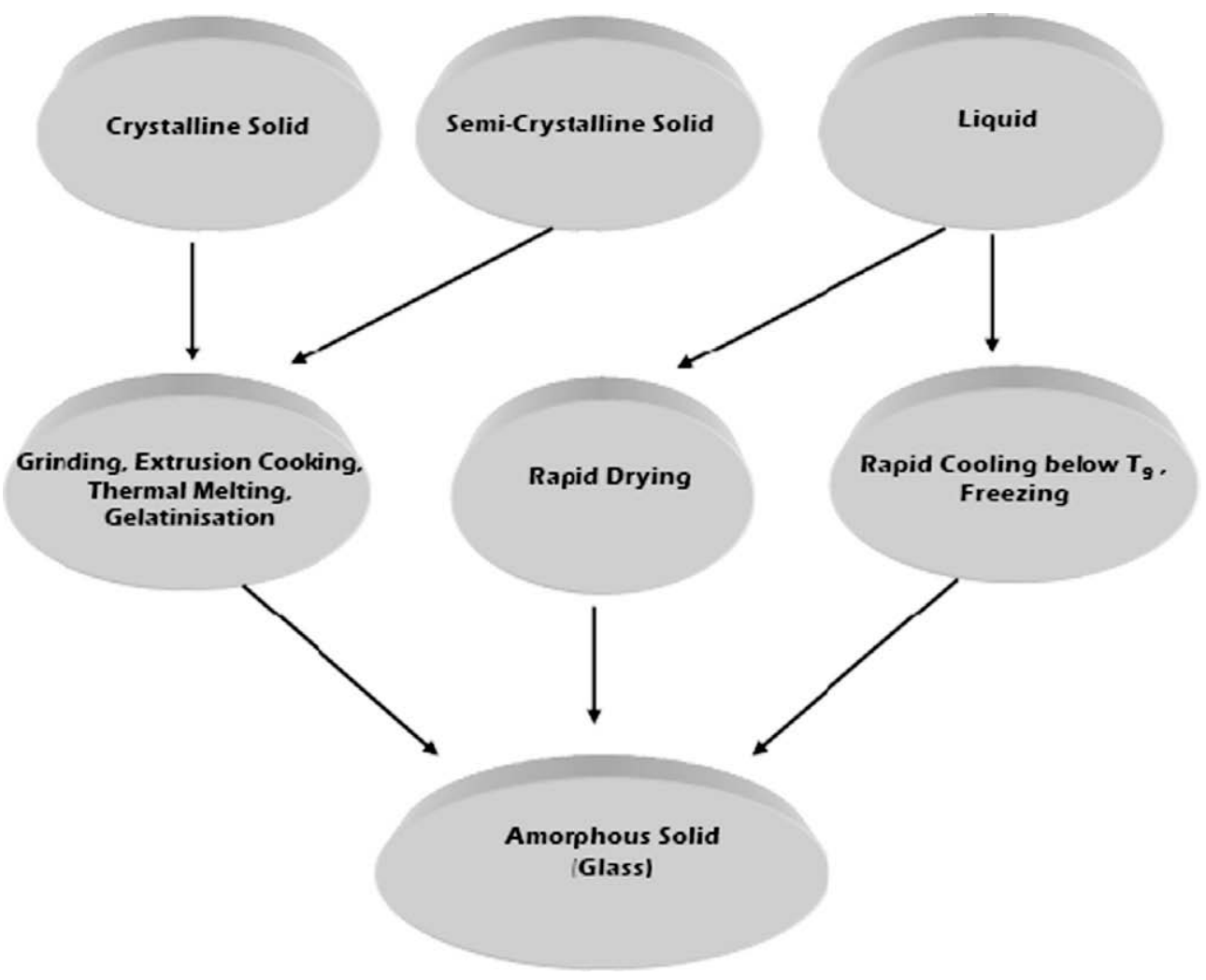

Fig. 1. Formation of physical structure of food powders (Bhandhari and Howes, 2004).

properties of individual sugars such as hygroscopicity, solubility, melting point and glass transition temperature influence differ ently on drying (Audu et al., 1978; Roos and Karel, 1991). Table 2 illustrates how different physical properties are correlated to the sticky behaviour of a food product. Stickiness is due to the combined effect of all of these properties during spray drying (Bhandari et al., 1997).

On heating, the amorphous material becomes viscous where its viscosity decreases sharply from $10^{12-14} \mathrm{~Pa}$ s to $10^{6-8}$ Pa s thereby leading to stickiness (Downton et al., 1982; Wallack and King,

Table 1

Experimental conditions recently optimized for the encapsulation of a few different food ingredients by spray-drying.

\begin{tabular}{|c|c|c|c|c|c|}
\hline Encapsulated ingredient & Wall material & $\begin{array}{l}\text { Food } \\
\text { temperature }\left({ }^{\circ} \mathrm{C}\right)\end{array}$ & $\begin{array}{l}\text { Air inlet } \\
\text { temperature }\left({ }^{\circ} \mathrm{C}\right)\end{array}$ & $\begin{array}{l}\text { Air outlet } \\
\text { temperature }\left({ }^{\circ} \mathrm{C}\right)\end{array}$ & References \\
\hline Anhydrous milk fat & Whey protein/lactose & 50 & 160 & 80 & Young et al. (1993) \\
\hline Ethyl butyrate ethyl caprylate & Whey protein/lactose & 5 & 160 & 80 & Rosenberg and Sheu (1996 \\
\hline $\begin{array}{l}\text { Oregano, citronella and } \\
\text { marjoram flavours }\end{array}$ & Whey proteins/milk proteins & NR & 185-195 & $85-95$ & Baranauskienė et al. (2006) \\
\hline Soya oil & Sodium caseinate/carbohydrate & NR & 180 & 95 & Hogan et al. (2001) \\
\hline $\begin{array}{l}\text { Calcium citrate calcium } \\
\text { lactate }\end{array}$ & $\begin{array}{l}\text { Cellulose derivatives/ } \\
\text { Polymethacrylic acid }\end{array}$ & NR & $120-170$ & $91-95$ & Oneda and Ré (2003) \\
\hline Lycopene & Gelatin/sucrose & 55 & 190 & 52 & Shu et al. (2006) \\
\hline Fish oil & Starch derivatives/glucose syrup & NR & 170 & 70 & Drusch et al. (2006) \\
\hline Cardamom essential oil & Mesquite gum & Room T & $195-205$ & $150-115$ & Beristain et al., (2001) \\
\hline Arachidonyl L-Ascorbate & $\begin{array}{l}\text { Maltodextrin/gum arabic/soybean } \\
\text { polysaccharides }\end{array}$ & NR & 200 & $100-110$ & Watanabe et al. (2004) \\
\hline Cardamom oleoresin & $\begin{array}{l}\text { Gum arabic/modified starch/ } \\
\text { maltodextrin }\end{array}$ & NR & $176-180$ & $115-125$ & Krishnan et al. (2005) \\
\hline Bixin & Gum arabic/maltodextrin/sucrose & Room T & 180 & 130 & Barbosa et al., (2005) \\
\hline D-Limonene & $\begin{array}{l}\text { Gum arabic/maltodextrin/modified } \\
\text { starch }\end{array}$ & NR & 200 & $100-120$ & Soottitantawat et al. (2005a) \\
\hline L-Menthol & Gum Arabic/modified starch & NR & 180 & $95-105$ & Soottitantawat et al. (2005b) \\
\hline Black pepper oleoresin & Gum Arabic/modified starch & NR & $176-180$ & $105-115$ & Shaikh et al. (2006) \\
\hline Cumin oleoresin & $\begin{array}{l}\text { Gum arabic/maltodextrin/modified } \\
\text { starch }\end{array}$ & NR & $158-162$ & $115-125$ & \\
\hline Fish oil & Sugar beet pectin/glucose syrup & NR & 170 & 70 & Drusch (2006) \\
\hline Caraway essential oil & $\begin{array}{l}\text { Milk proteins/whey proteins/ } \\
\text { maltodextrin }\end{array}$ & NR & $175-185$ & $85-95$ & Bylaite et al. (2001) \\
\hline Short chain fatty acid & Maltodextrin/ Gum arabic & NR & 180 & 90 & Teixeira et al. (2004) \\
\hline
\end{tabular}

NR: not reported. 
Table 2

Physical properties of sugars and stickiness behaviour during spray drying.

\begin{tabular}{|c|c|c|c|c|c|}
\hline Sugars & Hygroscopicity $^{\mathrm{a}}$ (relative $^{\mathrm{g}}$ ) & Melting point $\mathrm{t}^{\mathrm{b}}\left({ }^{\circ} \mathrm{C}\right)$ & Solubility in water ${ }^{\mathrm{c}}$ at $60{ }^{\circ} \mathrm{C}(\% \mathrm{w} / \mathrm{w})$ & $\mathrm{T}_{\mathrm{g}}^{\mathrm{d}}\left({ }^{\circ} \mathrm{C}\right)$ & Stickiness $^{\mathrm{e}}$ (relative) \\
\hline Lactose & + & 223 & 35 & 101 & + \\
\hline Maltose & ++ & 165 & $52^{f}$ & 87 & $(++)$ \\
\hline Sucrose & +++ & 186 & 71 & 62 & +++ \\
\hline Glucose & +++++ & 146 & 72 & 31 & +++++ \\
\hline Fructose & ++++++ & 105 & 89 & 5 & ++++++ \\
\hline
\end{tabular}

${ }^{a}$ Audu et al. (1978) - at water activity below 0.5 .

beast and Astle (1979).

${ }^{c}$ Deman (1976).

${ }^{\mathrm{d}}$ Labuza (1995)

eRigby et al. (1996)

${ }^{\mathrm{f}}$ At $25^{\circ} \mathrm{C}$ - Perry et al. (1973). Number of +symbol indicates the relative degree of hygroscopicity or stickiness, assumption made when the symbol(s) under bracket.

1988). The sticky behaviour depends on both the sugar content and temperature of the product (Bhandari et al., 1997). Quantifiable sticky behaviour of an amorphous product is observed at temper atures about $20^{\circ} \mathrm{C}$ above glass transition temperature (Bhandari et al., 1997). Table 3 shows the effect of the increase in tempera ture of product above $T_{g}$ on the structural characteristics of the product (Labuza, 1995). Bhandari et al. (1997) suggested that the problem of stickiness could be avoided by undertaking the spray drying operation within $20^{\circ} \mathrm{C}$ above the prevailing glass transition temperature. This suggestion is based on Table 3 .

It is essential to know the glass transition temperature of a sam ple that undergoes drying. To this end, Couchman and Karasz's (1978) equation (Eq. (1)) for multi component mixture could safely be used (Bhandari et al., 1997)

$T_{g} \frac{w_{1} \Delta C_{p 1} T_{g 1}+w_{2} \Delta C_{p 2} T_{g 2}+w_{3} \Delta C_{p 3} T_{g 3}}{w_{1} \Delta C_{p 1}+w_{2} \Delta C_{p 2}+w_{3} \Delta C_{p 3}}$

where $T_{g}$ is the glass transition temperature of the mixture, $w_{1} w_{2}$ and $w_{3}$ are mass fractions of two solutes and water respectively. $T_{g 1}, T_{g 2}$ and $T_{g 3}$ are glass transition temperatures $(\mathrm{K})$ of 2 solutes and water $(138 \mathrm{~K})$, respectively. $\Delta C_{p 1}, \Delta C_{p 2}$ and $\Delta C_{p 3}$ are step changes in specific heat capacities of two solutes and water respectively.

To minimize the stickiness problem process and material sci ence based approaches are in place. Process based approaches in clude: the mechanical scraping of the chamber wall; introduction of cold air at the bottom; and, the use of low temperature low humidity air. Changing the glass transition temperature of feed solution by introduction of drying agents is an example of the materials science based approach (Downton et al., 1982). Process based modifications are not easy and can be economically non via ble, for example stickiness could be avoided by keeping the outlet temperature of air below $50{ }^{\circ} \mathrm{C}$ or even at ambient temperature, however the production becomes economically non viable. The material science based approach has its own limitations, for exam ple, addition of a large amount of drying additive such as malto dextrins $(4060 \% \mathrm{w} / \mathrm{w})$ is required in the case of sucrose solution to convert it into amorphous powder (Adhikari et al., 2007a) and $35 \%$ to $45 \%(\mathrm{w} / \mathrm{w})$ of maltodextrin (DE6) required for fruit juices such as blackcurrant, apricot and raspberry (Bhandari et al., 1993). More than $60 \%$ of maltodextrin was required for spray dry

Table 3

Effect of the increase in temperature of product above $T_{g}$ on the structural characteristics of the product (Labuza, 1995).

\begin{tabular}{ll}
\hline Temperature above $T_{g}\left({ }^{\circ} \mathrm{C}\right)$ & Characteristics \\
\hline 10 & Begins to show adhesion \\
20 & Shows stickiness \\
$30-50$ & Crystallization at room temperature \\
$>50$ & Shows total collapse and flow \\
\hline
\end{tabular}

ing of orange juice (Shrestha et al., 2007). Addition of such large amount of these carriers alters the resultant powder quality and risks consumer disapproval. Surface modification of droplets/par ticles is a novel way to minimize this problem (Adhikari et al., 2009a).

Surface modification can be done with proteins by taking into account of both film forming property of protein to encapsulate the sugars and the surface activity of proteins (Adhikari et al., 2009a). In the study conducted by Adhikari et al. (2009a) it was found that the surface tension values of both sucrose sodium case inate and sucrose whey protein isolate solutions were close to the surface tension values of the corresponding protein concentrations. This indicates that where the surface activity of a sucrose protein solution is concerned, it has already reached the maximal level of protein occupation at the air water interface, even at a low protein concentration such as $0.1250 .25 \%(w / w)$. Since the sucrose mole cules are not responsible for lowering of the surface tension of su crose protein solutions, the migration of protein molecules at air water interface is responsible for this. The proteins being surface active preferentially migrate to the air water interface. This pref erential migration combined with their film forming property upon drying, is responsible for overcoming the stickiness of sugar pro tein solutions. These authors further observed that a smooth non sticky skin was formed on both the surfaces of whey protein isolate and sodium caseinate films immediately after they were subjected to drying air. Although skin formation was observed with maltodextrins during drying, it took much longer for this skin to develop into a thicker shell, compared with proteins.

\section{Characterization of surface composition of spray-dried emulsions}

Surface composition of powders plays an important role during its end use (Kim et al., 2003). Understanding the mechanism of the powder surface formation in terms of the compositional aspect and the ability to control the surface composition will be of great use in quality improvement of milk powder and development of new products (Kim et al., 2002). The surface composition of powders significantly influences the particle liquid interactions (e.g. wetta bility, dispersibility) and the particle particle interactions (flow ability, stickiness). These interactions, in turn are influenced by particle size, shape, bulk density and chemical composition of the particle surface (Fäldt et al., 1993; Kim et al., 2003; Millqvist Fureby et al., 2001; Nijdam and Langrish, 2006). The surface com position of food powders is determined by electron spectroscopy for chemical analysis (ESCA). Fig. 2 depicts the principle of ESCA (Fäldt et al., 1993).

Using ESCA data, a numerical method based on matrix inversion is available to determine the surface coverage of individual compo nents (Fäldt et al., 1993; Kim et al., 2002; Shrestha et al., 2007; Adhikari et al., 2009a). For each of the elements: C, O and $\mathrm{N}$ in 
Photoelectron Spectrum

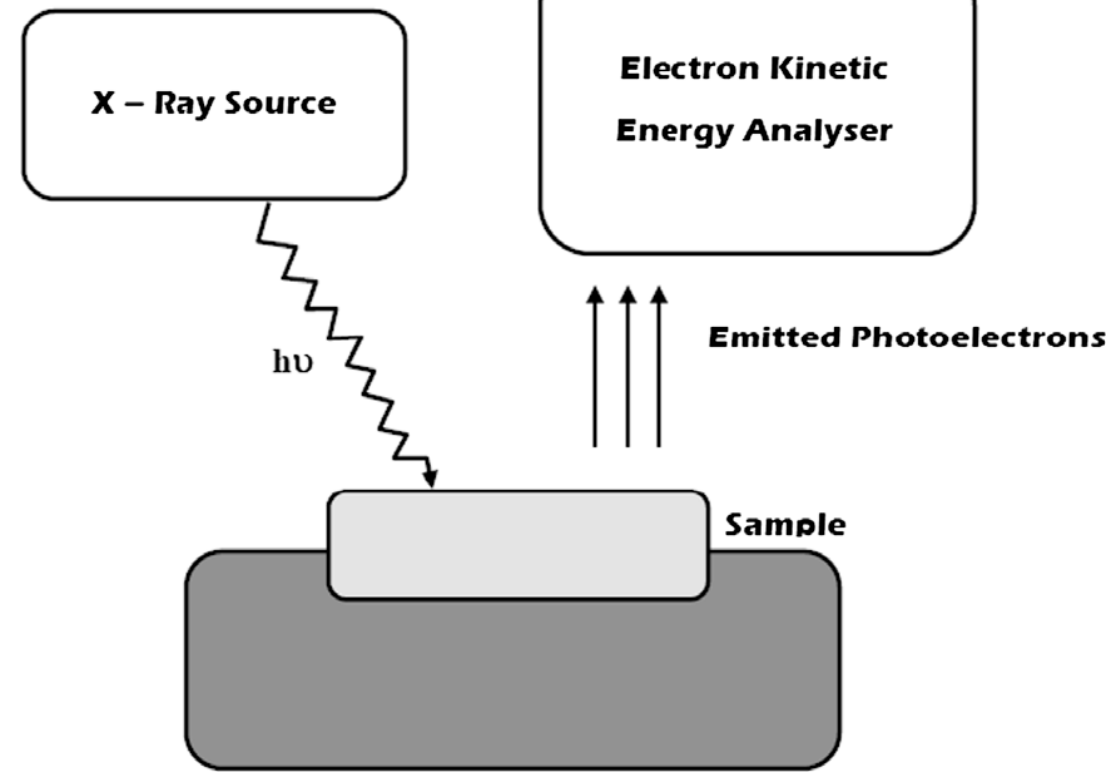

Fig. 2. The principle of Electron Spectroscopy for Chemical Analysis (ESCA) (Fäldt et al., 1993).

the powder sample, the relative amount of protein, fat and sugars on the particle surface can be calculated by using Eqs. (3) (5) (Fäldt et al., 1993)

$$
\begin{array}{ll}
I_{\text {sample }}^{C} & I_{f}^{C} \cdot \gamma_{f}+I_{p}^{C} \cdot \gamma_{p}+I_{s}^{C} \cdot \gamma_{s} \\
I_{\text {sample }}^{O} & I_{f}^{O} \cdot \gamma_{f}+I_{p}^{O} \cdot \gamma_{p}+I_{s}^{O} \cdot \gamma_{s} \\
I_{\text {sample }}^{N} & I_{f}^{N} \cdot \gamma_{f}+I_{p}^{N} \cdot \gamma_{p}+I_{s}^{N} \cdot \gamma_{s}
\end{array}
$$

where $I_{\text {sample }}^{C}, I_{\text {sample }}^{O}$ and $I_{\text {sample }}^{N}$ are the relative amounts of carbon, oxygen and nitrogen in the sample; $I_{f}^{C}, I_{p}^{C}$ and $I_{s}^{C}$ are relative amounts of carbon in fat, protein and sugar; $I_{f}^{O}, I_{p}^{O}$ and $I_{s}^{0}$ are relative amounts of oxygen in fat, protein and sugar; and $I_{f}^{N}, I_{p}^{N}$ and $I_{s}^{N}$ are relative amounts of nitrogen in fat, protein and sugar and $\gamma, \gamma_{p}$ and $\gamma_{s}$ are the fractions of area covered with fat, protein and sugar, respec tively. The fraction of area covered by each component can be esti

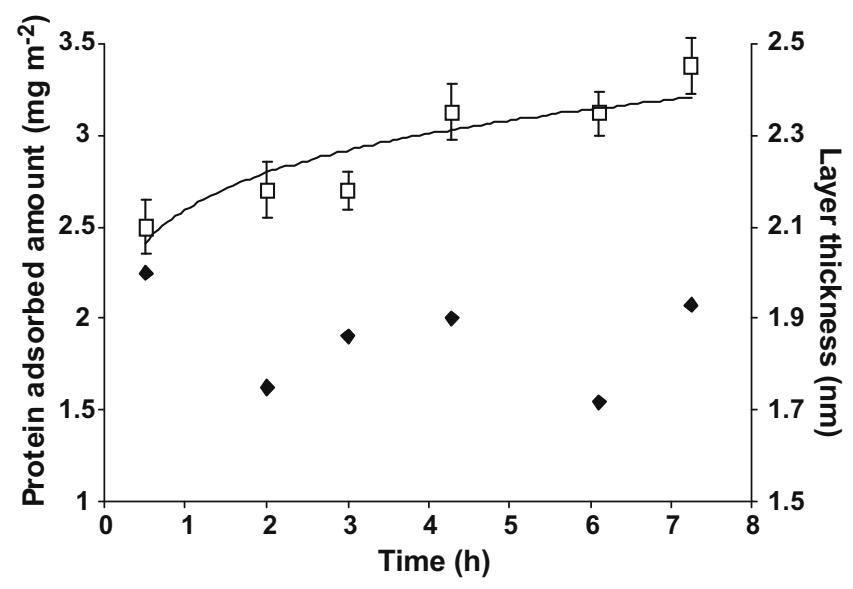

Fig. 3. Adsorbed layer of $\beta$-lactoglobulin $(0.1 \mathrm{w} / \mathrm{w} \%$ protein, $\mathrm{pH} 6.0)$ at the air-water interface. The adsorbed amount $(\square)$ and the layer thickness $(\downarrow)$ are plotted against time (Horne et al., 1998). mated by solving the above equation by matrix inversion, as previously reported by Fäldt et al. (1993) (see Figs. 3 and 4).

In the work carried out by Kim et al. (2003), the distribution of milk components in the near surface region of the industrial spray dried milk powders (skim and whole milk powders) was studied using ESCA combined with the free fat extraction procedures. The results showed that the surface composition of powders is sur prisingly different from the bulk composition of powders (Kim et al., 2002; 2003; Nijdam and Langrish, 2006). The bulk composi tion of skim milk powder was $58 \%$ lactose, $41 \%$ protein and $1 \%$ fat while the surface was covered with $36 \%$ lactose, $46 \%$ protein and $18 \%$ fat. On the other hand, for whole milk powder with bulk com position of $40 \%$ lactose, $31 \%$ protein and $29 \%$ fat, the surface was covered with $2 \%$ lactose, negligible amount of protein and $98 \%$ fat. It can be seen from these results that there is an over represen tation of fat on surface compared to that of the bulk powder. This shows that there is segregation among the components and the fat is preferentially accumulated on the surface. It was also high lighted that the outermost surface of milk powders was largely covered by unprotected fat particles. Below this, fat globules pro tected by protein or individual proteins were found (Kim et al., 2003). The above surface composition data were verified by Kim et al. (2002) by further experimentation, such as surface structure studies, fat localization studies, wetting tests and the measure ment of surface oxygen test during storage.

Fäldt and Bergenståhl (1995) studied the influence of the oil phase on the fat encapsulation during spray drying of emulsions containing sodium caseinate and lactose. This work was further ex tended to study the influence of lactose on the fat encapsulation in spray dried sodium caseinate stabilized emulsions having differ ent fat contents (Fäldt and Bergenståhl, 1995; Vega and Roos, 2006; Vignolles et al., 2007). ESCA revealed that the powder sur faces were usually dominated by protein (Fäldt and Bergenståhl, 1994; Abdul Fattah et al., 2007) while fat was mostly encapsulated inside the particles. Another interesting finding in this study is that 


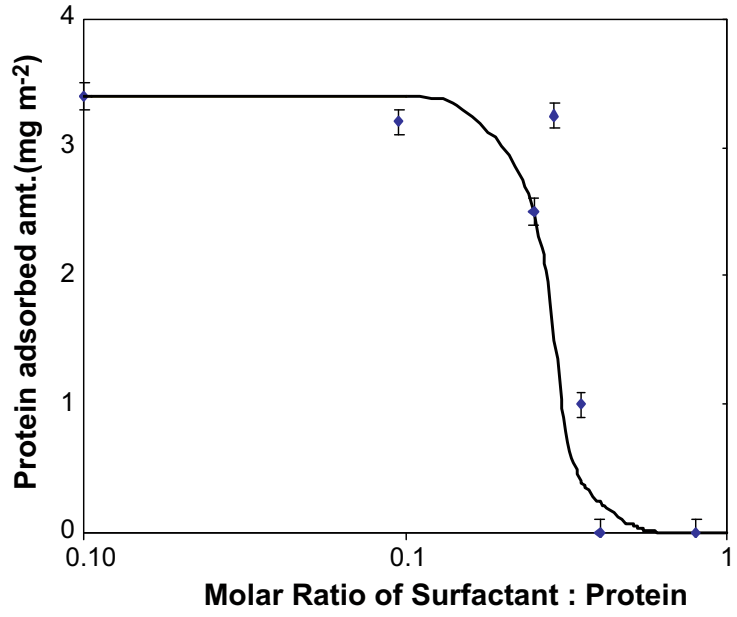

Fig. 4. Displacement of $\beta$-lactoglobulin from the interface by hydrogenated surfactant $\left(\mathrm{H}-\mathrm{C}_{12} \mathrm{E}_{6}\right)$. Normalized adsorbed amount of protein is plotted against the surfactant: protein molar ratio. The points correspond to experiments at different surfactant concentrations. The fitted curve is complementary error function in $\log (\mathrm{R})$ whose parameters have been varied to produce the best fit seen here (Horne et al., 1998).

the presence of lactose is important in obtaining complete encap sulation of the fat after spray drying of sodium caseinate stabilized soybean oil emulsions. The role of lactose can be explained as fol lows. Before drying, the protein is the most surface active compo nent in the emulsion and is accumulated at the air water interface of the drying droplets (Fäldt and Bergenståhl, 1994; Elversson and Millqvist Fureby, 2006). The protein in the surface film of the emulsion is completely hydrated and the loss of water during dry ing would result in the shrinkage of the film. However, if the emul sion contains lactose, the lactose can replace the water to some extent and keep the protein solubilized after drying and thereby lactose reduces the shrinkage. This leads to the increase in stability of the sodium caseinate film on the powder surface, and less fat leaks out onto the powder surface (Fäldt and Bergenståhl, 1995). In a latter study conducted by the same authors, it was revealed that the addition of lactose to a whey protein stabilized emulsion prevents the increase in emulsion droplet size when emulsions were spray dried and redispersed. For powders with or without lactose, the surface composition was not very different (Fäldt and Bergenståhl, 1996). Gaiani et al (2006) found that that the surface of native phosphocaseinate powder (NPC), NPC powder containing lactose (NPC $+\mathrm{L})$ and NPC powder containing lactose and soluble minerals from ultrafiltrate (NPC + UF) was mainly covered by pro teins. Millqvist Fureby et al. (2001) studied the surface composi tion of protein stabilized and pre heat treated emulsions and showed that the powder surface coverage of protein decreased with increasing degree of protein denaturation and that it led to smaller droplet sizes upon atomization. This establishes that the state of protein (native or unfolded/aggregated) used as emulsifiers can have a great impact on both emulsion properties and the sur face composition of the spray dried powders produced from these emulsions. It is important that the proteins are in a native state otherwise if the proteins are denatured they make the emulsion less stable and more fat could be expected at the powder surface. This surface fat not only worsens the stickiness during drying, but it also leads to fat oxidation and the powder becomes rancid on storage. Williams and Prins (1996) observed that diffusion of proteins to and from the interface is likely only if the protein mol ecules retain their native structure. This is because the structurally denatured (unfolded) proteins do not have driving force to desorb or adsorb (Fainerman et al., 2006).
The surface composition of a spray dried emulsion is usually determined by the ingredients and emulsion processing (Fäldt and Bergenståhl, 1995; Millqvist Fureby et al., 1999). It was ob served that if the proteins were the only emulsifiers present, they would adsorb to the oil interfaces, normally in proportion to their concentrations in the aqueous phase (Hunt and Dalgleish, 1994a,b). If the solution contains a surface active component such as protein, this was shown to dominate the surface of the spray dried powder (Fäldt, 1995; Fäldt and Bergenståhl, 1994).

Surface composition of spray dried emulsions composed of var ious milk protein fractions, lactose and rapeseed oil is influenced by the type of protein and the $\mathrm{pH}$ treatment of the protein (Millq vist Fureby et al., 1999). The surface activity of protein, protein size and other properties of proteins are important factors in determin ing the protein coverage of powders (Millqvist Fureby et al., 1999). The protein and lactose coverage are increased at high $\mathrm{pH}$, while the fat coverage is significantly reduced (Millqvist Fureby et al., 1999). The $\mathrm{pH}$ of the solution affects the properties of the protein and thereby the surface tension and adsorption kinetics. Sodium caseinate is efficient at encapsulating the rapeseed oil, which is present to a level of $35 \%$ or less at the surface (Millqvist Fureby et al., 1999).

\section{Effect of proteins on emulsions and spray-dried food powders}

Emulsions that are stabilized only by protein are very stable to coalescence, provided sufficient protein is available to fully cover the droplet surface (Tcholakova et al., 2002, 2006a; van Aken, 2003). Upon adsorption, proteins form thick adsorption layers, in which the protein molecules are often bound together by cohesive bonds and have a low lateral mobility (van Aken, 2003; Clark et al, 1990). Adsorbed protein layers are very effective in stabilizing thin films between emulsion droplets due to their electric charge, thick ness and their high elasticity (van Aken, 2003). Although the study of food emulsion systems generated from proteins is dominated by research into milk proteins, there exists a growing interest in the use of vegetable proteins from cereals and legumes for the forma tion and stabilization of food emulsions and foams (Rodríguez Niño et al., 2005).

Competitive adsorption is a common characteristic of many systems containing a mixture of surface active species such as pro teins. Competitive surface adsorption between surface active sub stances in liquid formulations can be used to better encapsulate and protect a sensitive protein/enzyme formulation and also to modify the powder properties. Surface competition during spray drying involves adsorption of surface active components to the air/liquid interface of drying droplets (Elversson and Millqvist Fureby, 2006). Competitive adsorption between two proteins, bo vine serum albumin (BSA) and $\beta$ lactoglobulin to the air water interface during spray drying process was investigated by Lands tröm et al. (2000). Solutions consisting of mixtures of pyrene la belled BSA and $\beta$ lactoglobulin were spray dried together with dextran. The fluorescence quenching method was used to deter mine the adsorbed fraction of protein at the powder surface (Landström et al., 2000). The adsorbed fraction of protein at the surface $X_{\text {ads }}$ was calculated from the fluorescence intensity mea sured in an oxygen atmosphere $\left(I_{0}\right)$ and the intensity measured in an argon atmosphere (I) (Landström et al., 1999).

$X_{\text {ads }} \quad\left(\begin{array}{ll}1 & \frac{I}{I_{0}}\end{array}\right)$

The apparent surface load of protein, $\Gamma^{*}$, was determined from the adsorbed fraction of protein at the powder surface $\left(\mathrm{mg} \mathrm{m}^{2}\right)$, $X_{\text {ads }}$, the surface area of the powder, $A(\mathrm{mg} / \mathrm{g})$, and the amount of protein in the powder, $C(\mathrm{mg} / \mathrm{g}$ powder $)$ : 


$$
\Gamma^{*} \quad C \frac{X_{\mathrm{ads}}}{A}
$$

Results showed that $\beta$ lactoglobulin started to appear at the powder surface at a concentration as low as $0.033 \%(\mathrm{w} / \mathrm{w})$ of the dry material, giving an apparent surface load of $0.07 \mathrm{mg} / \mathrm{m}^{2}$. As the protein concentration increased the apparent surface load in creased sharply to $0.9 \mathrm{mg} / \mathrm{m}^{2}$, thereafter the increase of the amount of protein at the surface was less effective (Landström et al., 2000). $\beta$ Lactoglobulin was found to have a greater tendency for larger surface load compared to BSA (Landström et al., 1999, 2000). This indicates that $\beta$ lactoglobulin is more surface active than BSA during spray drying. It was also found that the protein adsorption during spray drying gave the same total apparent sur face load of protein independent of whether a single protein or a mixture of proteins was used (Landström et al., 2000). This means that one can choose a protein that can provide the best surface load.

It has been established that the composition of the droplet sur face is preserved during spray drying (Fäldt and Bergenståhl, 1994; Millqvist Fureby et al., 1999; Landström et al., 2000). The surface active components, such as proteins, in the spray dried solution adsorb in preference to the air liquid interface of the droplet and hence dominate the powder surface. The adsorption process of proteins at the air water interface is regarded as a three step pro cess (MacRitchie and Alexander, 1963a,b,c): Firstly, diffusion of molecules from the bulk solution to the subsurface region; secondly, the adsorption of molecules from a subsurface to the air water interface; and finally, it is the reconformation or rear rangement of adsorbed molecules within the surface layer. The adsorption behaviour of protein to the air water interface during spray drying can be assumed to be mainly diffusion controlled due to the short lifetime of the droplet. The size of the protein will be the dominating factor in diffusion controlled adsorption. The smaller the size of the proteins, faster the adsorption of proteins to the air water interfaces (Landström et al., 2000). The minimum theoretical time to reach the surface coverage of protein attained through diffusion limited adsorption can be calculated by the established expression (8) (MacRitchie and Alexander, 1963a):

$$
t \frac{\pi n^{2}}{4 C_{b}^{2} D}
$$

where $C_{b}$ is the bulk concentration ( $\mathrm{mol} \mathrm{m}^{3}$ ), $D$ is the protein bulk diffusion coefficient $\left(\mathrm{m}^{2} \mathrm{~s}{ }^{1}\right), n$ is the number of moles per unit area $\left(\mathrm{mol} \mathrm{m}{ }^{2}\right.$ ) and $t$ the time elapsed since the formation of the fresh air/water interfaces(s).

The theoretical time for reaching the apparent surface load of protein would be about $0.20 .3 \mathrm{~s}$. During spray drying too, the pro teins require this time scale to diffuse to the air water interface (Fäldt, 1995). This supports the argument that the diffusion is the main mechanism with which proteins migrate to the air water interface during spray drying process. However, Landström et al. (2000) argue that not only diffusion but also the high shear rate influences the protein adsorption at air water interface during spray drying. When an aqueous solution of lactose sodium casei nate was spray dried, it was found that the sodium caseinate dom inated the surface composition of the powder (Fäldt and Bergenståhl, 1994).

Many oil in water type food emulsions are stabilized primarily by an adsorbed layer of protein forming a protective steric barrier around the dispersed droplets (Chen et al., 1993). Most of the ad sorbed proteins exist in conformations that are different from their native states, although for globular proteins the change in second ary structure may be limited (Dalgleish, 2006). This is due to the tendency of hydrophobic parts of the molecules to be adsorbed to the hydrophobic interface with a significant distortion or disrup tion of their secondary or tertiary structures (Fang and Dalgleish, 1998).

Elversson and Millqvist Fureby (2005) and Vehring(2008) investigated to what extent an aqueous two phase systems (ATPS) could encapsulate and protect the secondary structure of a protein during spray drying. The ATPS consisted of polyvinyl alcohol (PVA) and dextran solutions in different ratios. Here a model protein, bo vine serum albumin (BSA) and, in some trials trehalose, was added to the ATPS prior to spray drying. The ATPS concept was successful with regard to protein encapsulation during spray drying, thus minimizing the exposure of protein to the large air liquid interface of droplets. However, PVA could not be considered appropriate for this purpose because the dried sample suffered from extensive aggregation of BSA. PVA increased the loss of native structure and dextran was not sufficient as a stabilizer. BSA dominated the powder surface in the absence of PVA while in its presence the polymer mainly covered the powder surface (Elversson and Millq vist Fureby, 2005, 2006). It is interesting to note that although both PVA and BSA possess similar equilibrium surface activities (approximately $50 \mathrm{mN} / \mathrm{m}$ ) a higher accumulation of PVA compared to that of BSA is observed at the powder surface. This can be due to the smaller size of PVA compared to BSA. Since mass transport in the drying droplet is mostly controlled by both diffusion and con vection, the size of polymer and protein can become controlling factor. The different adsorption kinetics of both PVA and BSA could be another reason for the outcome of the competition between PVA and BSA for the interface. The random coil configuration of PVA in solution would be beneficial for the faster rate of adsorption as compared to the ordered configuration of BSA which has to be un folded for adsorption to occur (Elversson and Millqvist Fureby, 2005, 2006).

Caseins are more surface active than whey proteins in the sense that they give a lower surface tension at air water interface. Hence, it could be assumed that caseinate samples would give a higher surface coverage than whey proteins (Millqvist Fureby et al., 1999). Brun and Dalgleish (1999) showed that caseins and whey proteins do not exchange readily between the interfaces and bulk of emulsions at room temperature and neutral $\mathrm{pH}$. Case ins neither displace whey proteins adsorbed to emulsion surface nor do they interact with the adsorbed whey proteins even at ele vated temperatures. However if the layer of adsorbed whey pro teins is not saturated casein may co adsorb. The $\alpha$ lactalbumin and $\beta$ lactoglobulin denature when they are heated at tempera tures greater than $70^{\circ} \mathrm{C}$ and at this stage they may interact with $\kappa$ casein and $\alpha_{s 2}$ caseins.

Whey proteins once adsorbed at the interface create a more elastic interface compared to the caseins. The higher the $\beta$ lacto globulin content, the more elastic is the interface. The elasticity values for whey proteins are much higher at the $n$ dodecane water interface than those at the air water interface (Rouimi et al., 2005). Murray et al. (1998) found that films exhibit higher elastic moduli at the oil water interface than the air water interface. This was due to a greater unfolding and flexibility of the protein at the oil water interface as a result of better solvation of the hydrophobic regions of the polypeptide by the oil.

Whey protein isolates (WPI) and caseinates have been recog nized for their emulsifying and gelation properties. The adsorption behaviour of WPI is very much different from that of caseinate (Hunt and Dalgleish, 1994a; Sánchez and Rodríguez Patino, 2005; Ye, 2008). Hunt and Dalgleish (1994a) reported the limiting surface concentrations required to stabilize emulsions containing casei nate and WPI to be 1 and $1.5 \mathrm{mg} / \mathrm{m}^{2}$, respectively. This difference is consistent with the more flexible nature of caseins compared to the globular whey proteins. The maximum surface concentra tion of both proteins was $3.2 \mathrm{mg} / \mathrm{m}^{2}$ at protein concentrations $>2.25 \%(\mathrm{w} / \mathrm{w})$ in the bulk. When protein concentration was the lim 
iting factor, caseins were able to cover and stabilize greater inter facial area than globular whey proteins (Sánchez and Rodríguez Patino, 2005; Ye, 2008). Hunt and Dalgleish (1994) found that WPI concentration of $1 \%$ in bulk ( $20 \%$ oil and $79 \%$ water) resulted in a WPI surface concentration of $2.21 \mathrm{mg} / \mathrm{m}^{2}$, which they sug gested to be the mono molecular layer concentration of this protein. In order to find the order of magnitude of this concentra tion, we calculated the mono molecular layer concentration of $\beta$ lactoglobulin on a $0.75 \mu \mathrm{m}$ fat droplet. This is the average droplet size of the emulsion reported by the same authors. As $\beta$ lactoglob ulin is a major constituent of WPI, the mono molecular layer con centration of the former will provide a reasonable estimate of the latter. Using molecular weight and solid density values of $\beta$ lacto globulin $\left(18,360 \mathrm{Da}, 1.261 \mathrm{~g} / \mathrm{cm}^{3}\right)$ (Berlin and Pallansch, 1968), its molecular diameter can be calculated to be $35.88 \mathrm{~A}^{\circ}$. The concen tration required for $\beta$ lactoglobulin to form a mono molecular layer on the $0.75 \mu \mathrm{m}$ fat droplet is estimated to be $2.27 \mathrm{mg} / \mathrm{m}^{2}$ assuming $100 \%$ surface coverage and $1.95 \mathrm{mg} / \mathrm{m}^{2}$ assuming $86 \%$ coverage (due to repulsive effect). This supports Hunt and Dalgle ish (1994)'s suggestion that the surface protein concentration of $2.21 \mathrm{mg} / \mathrm{m}^{2}$, corresponding to $1 \% \mathrm{w} / \mathrm{w}$ bulk concentration, consti tutes a mono molecular layer protein concentration.

For caseinate stabilized emulsions with protein concentrations $>1.5 \% \mathrm{w} / \mathrm{w}$, there was less adsorption of $\kappa$ casein compared to the other caseins (Hunt and Dalgleish, 1994a). In these emulsions $\beta$ caseins preferentially adsorbed at the surface compared to $\alpha_{s 1}$ caseins at $<2 \%(w / w)$ protein concentrations (Ye, 2008). However, such preference was observed for neither $\alpha_{s 1}$ casein nor $\beta$ casein at $>2 \%(\mathrm{w} / \mathrm{w}$ ) protein concentrations (Hunt and Dalgleish, 1994a; Srinivasan et al., 1996). In emulsions stabilized by a model mixture of $\beta$ casein and $\alpha_{s 1}$ casein, the $\beta$ caseins adsorb in preference to $\alpha_{s 1}$ casein (Dickinson et al., 1988; Dickinson, 1994; Fang and Dal gleish, 1993) which can be attributed to comparatively lower sur face viscosity of $\beta$ casein than that of $\alpha_{s 1}$ (Dickinson, 2001). It has been shown that sodium caseinate has better encapsulation prop erties than micellar casein (Vega et al., 2005b). This result could be explained according to the molecular conformation, the high diffu sivity, and the strong amphiphilic characteristics of the individual caseins, which allow for a better distribution around the fat globule surface than micellar caseins (Dickinson et al., 2003). The surface shear viscosity is $10^{3} 10^{4}$ times larger for $\beta$ lactoglobulin than that of $\beta$ casein at the hydrocarbon water interface. The highly visco elastic character of adsorbed $\beta$ lactoglobulin is mainly due to the high $2 \mathrm{D}$ packing density and strong protein protein interactions compared to the loose packing and weak protein protein interac tions of casein monolayers (Dickinson, 2001). This means that the $\beta$ lactoglobulins will have a greater tendency to resist the desorption when they are on the surface. This fact can be of inter est when creating protein coated powders.

The interfacial dilatational properties of $\beta$ lactoglobulin and $\beta$ casein were studied over a wide range of protein concentrations at both the air water and oil water interfaces (Williams and Prins, 1996; Jones and Middelberg, 2003; Freer et al., 2004; Lucassen Renders et al., 2004; Maldonado Valderrama et al., 2005; Xu et al., 2008). It was found that no protein penetrates the oil phase to any great extent. At low bulk concentrations the $\beta$ lactoglobulin can unfold to a large degree thereby causing the surface structure to be, some extent similar to that of $\beta$ casein. At high bulk concen trations both proteins may form an interfacial network, through protein protein interactions and it is believed that for the globular proteins, it is very much stronger. On the one hand if $\beta$ casein is in higher concentration, either diffusion to and from the bulk or rear rangement between the adsorbed primary and multi layers takes place. On the other hand neither conformational changes nor diffu sion exchange was found taking place in case of $\beta$ lactoglobulin (Williams and Prins, 1996). It was revealed that, the stability of $\beta$ lactoglobulin containing emulsions significantly decreased after one day of shelf storage. This phenomenon, termed "the aging effect" is not related to changes in the mean drop size or protein adsorption. The aging effect is caused by conformational changes in the protein adsorbed layer accompanied with formation of non covalent bonds ( $\mathrm{H}$ bonds and hydrophobic interactions) be tween adsorbed molecules. These bonds transform the adsorption layer into a brittle shell, which is inefficient in protecting the drops against coalescence (Tcholakova et al., 2006b). Dalgleish (1996) stated that when a freshly prepared emulsion of oil stabilized with $\beta$ lactoglobulin was treated with casein, an increase in the diame ters of the particles was observed consistent with the adsorption of casein either along with or replacing the original interfacial pro tein. On the other hand when casein was added to an aged emul sion, no increase in diameter was observed, consistent with the increasing rigidity of the adsorbed protein, which makes it more difficult to replace. Similar results are observed for the displace ment of adsorbed $\beta$ lactoglobulin by small molecule weight surfac tants (Dalgleish, 1996; Mackie and Wilde, 2005). The results of this study confirmed that the displacement of the adsorbed proteins depends on the age of the emulsion. It is important to add casein into a freshly prepared emulsion of oil stabilized with $\beta$ lactoglob ulin rather than to an aged emulsion stabilized with $\beta$ lactoglobu lin if more casein is needed at the interface.

The effect of spray drying and reconstitution has been studied for oil in water emulsions (20.6\% maltodextrin, $20 \%$ soybean oil, $2.4 \%$ protein, $0.13 \mathrm{M} \mathrm{NaCl}, \mathrm{pH} 6.7$ ) with different ratios of sodium caseinate and whey protein (Sliwinski et al, 2003). After spray dry ing and reconstitution a portion of the adsorbed sodium caseinate, $\alpha_{s 1}$ casein and $\beta$ casein were found to be displaced by whey pro tein while $\alpha_{s 2}$ casein and $\kappa$ casein remained largely unchanged. These results are on par with the results obtained by Brun and Dal gleish (1999) that both $\beta$ casein and $\alpha_{s 1}$ casein were displaced by whey proteins during heating even though they are normally re garded as more surface active. The rate of displacement was tem perature dependant. Heating of $\beta$ lactoglobulin and $\kappa$ casein in combination did not lead to displacement of $\kappa$ casein. It was ob served that when the concentration of sodium caseinate in emul sion was high enough to completely cover the oil water interface, spray drying and reconstitution hardly affected the par ticle size distribution (Sliwinski et al., 2003). However, spray dry ing resulted in a strong increase of the droplet size distribution for emulsions of which contained greater than $70 \%(\mathrm{w} / \mathrm{w})$ whey protein. The adsorbed amount of protein for casein stabilized emulsion was $3 \mathrm{mg} \mathrm{m}^{2}$ while it was $4 \mathrm{mg} \mathrm{m}^{2}$ for whey stabilized emulsions with a maximum of $4.2 \mathrm{mg} \mathrm{m}^{2}$ for emulsions contain ing $80 \%$ whey protein on total protein. About one quarter of the available protein was adsorbed at the oil water interface. The dif ferences between adsorbed casein and their interaction with whey protein on heating are related to the difficulty to form disulphide linkages (Sliwinski et al., 2003). According to Tcholakova et al. (2006b) the heating of emulsions at $C_{\beta \text {-lactoglobulin }}>0.04 \% \mathrm{w} / \mathrm{w}$, $\mathrm{C}_{\text {electrolyte }}>150 \mathrm{mM}$, and $\mathrm{pH}>6.2$ leads to additional protein adsorption and irreversible attachment of the protein molecules in the formed adsorption multilayer. As a result, the emulsion coa lescence stability increases more than three times. The increased adsorption and the irreversible attachment of protein molecules in the adsorption layer are due to formation of disulphide bonds upon heating.

Maa et al. (1998) examined the effect of air liquid interface on the stability of two model proteins namely recombinant human Growth Hormone (rhGH) and recombinant human deoxyribonu clease (rhDNase). rhDNase was relatively stable while rhGH dena tured at the air liquid interface especially at high shear. rhGH had greater tendency to adsorb to the air liquid interface than rhDNase due to lower surface tension and higher foaming tendency. An 
other observation was that higher aggregation of rhGH occurred at high protein concentration and a large air liquid interfacial area. By addition of a surfactant or an anti foaming agent the rhGH aggregation was minimized (Maa et al. 1998). The state of aggrega tion was found to depend on the interactions between adsorbed protein layers on colliding droplets which ultimately was linked to protein surface coverage, the layer thickness, the surface charge density and the aqueous solution conditions (especially $\mathrm{pH}$, ionic strength, and calcium ion content) (Dickinson, 2001).

It was revealed that preferential migration of proteins (sodium caseinate and whey protein isolate) driven by their surface activity allows the generation of surface engineered powders of sugar rich foods. The use of both sodium caseinate and whey protein isolate in a pilot scale spray dryer led to an excellent recovery of 84 $85 \%$ of amorphous sucrose powder when just $0.125 \%$ of these pro teins were used in the solution (Adhikari et al., 2009b). This amount of protein addition is negligible compared to the amount of maltodextrin (DE6) $(>40 \% \mathrm{w} / \mathrm{w})$ required to obtain the same ex tent of recovery of sucrose powder under similar drying conditions (Truong et al., 2005). The greatly enhanced powder recovery with the addition of $0.125 \%$ of protein in solution is an indication of the protein rich film formed at the interface. This level of protein addition in sucrose solution was successful in overcoming the coa lescence of droplets as well as sticky interactions of the droplets or particles at the wall. Although the nature of the films and the dila tational elasticity of both sodium caseinate and whey protein iso late were quite different, these differences did not influence their ability to overcome the droplet droplet coalescence and particle wall stickiness. The presence of higher amount of proteins $(0.25 \%)$ or the use of different types of protein didn't make any dif ference (Adhikari et al., 2009b). This indicates that proteins can be used as 'smart drying aids' to minimize the stickiness of sugar and acid rich foods through surface modification. It was observed that there was a of trace amount of low molecular weight surfactants (LMS) present in industrially obtained sugar samples (Adhikari et al., 2007b). Therefore, it is of practical significance to investigate the implication of the presence of trace amount of LMS along with proteins in the surface stickiness of sugar rich foods.

\section{Effect of low molecular weight surfactants and proteins on emulsions and spray dried-food powders}

A series of studies were undertaken to understand the mecha nisms by which the LMS displace proteins at air water interface and oil water interfaces (Wilde and Clark, 1993; Dalgleish, 1997; Wilde et al., 2004; van Aken, 2003; Dalgleish, 2006). The interfacial layers of many oil in water emulsions contain proteins, in many cases mixed with other surfactants (Dalgleish, 2006). The types of emulsifier or foaming agents used in foods are low molecular weight surfactants such as mono and diglycerides (Cremodan), phospholipids, sodium stearoyl lactate, diacetyl tar taric acid ester of mono and diglycerides, polysorbates, lecithin and macromolecules such as proteins and some hydrocolloids (Romoscanu and Mezzenga, 2005; Bezelgues et al., 2008). Pro tein surfactant interactions are of importance in a wide range of applications, particularly in the food industry. It is known that the properties of the interfacial layers depend not only on the quantities of materials adsorbed but also their structures (Dalgle ish, 2006). Dalgleish (1997) stated that the composition of the interfacial layer is governed mostly by what is present at the mo ment the emulsion is formed.

Proteins and surfactants stabilize interfaces by different mech anisms (Dalgleish, 1996). The composition and structure of the stabilizing layer is determined by competitive adsorption bet ween proteins and surfactants at the interface and by the nature of surfactant protein interactions, both at the interface and in the bulk aqueous phase (Dickinson and Woskett, 1989). Proteins form an immobile viscoelastic network whereas lipids and surfactants rely on high degree of mobility to stabilize interfaces by the Gibbs Marangoni mechanism. Since the two mechanisms are incompatible, the addition of surfactant leads to competition be tween the two resulting in the displacement of protein from the interface. The adsorption of surfactant weakens the protein net work and reduces the stability of the foam. Individually, the vis coelastic and Marangoni mechanisms produced highly stable dispersions (Wilde and Clark, 1993). The proteins do not lower the interfacial tension as much as simple surfactants do, but effective saturation of the surface is reached at molar protein con centrations $10^{3} 10^{4}$ times lower than for the simple surfactants. At higher concentrations in the bulk phase, the surfactants lower the interfacial tension much more than the proteins due to the better packing of the small amphiphiles in the vicinity of the Gibbs plane (Dimitrova et al., 2004). Vast majority of food emul sions comprise both proteins and surfactants that compete for space at the interface (Mackie et al, 2000) and in those foods, the stability of colloidal dispersed phases is primarily dependent on protein films adsorbed at the interface (Rodríguez Patino et al., 2003). In contrast to the positive effects on emulsion stability, the addition of surfactant causes destabilization through an enhance ment of droplet aggregation due to supposed disruption of ad sorbed protein layers during air incorporation or whipping (Courthaudon et al., 1991). This finding is supported by Mackie et al. (1999) who have shown that small quantities of surfactant if added to protein stabilized interface reduce the stability rather than enhance it.

Golemanov et al (2008) proposed a new class of surfactant mix tures, which are particularly suitable for studies on foam dynamic properties. The surfactant mixture contained an anionic surfactant sodium lauryl dioxyethylene sulphate (SLES), zwitterionic surfac tant cocoamidopropyl betaine (CAPB) and medium chain fatty acids, lauric acid (LAc) and myristic acid (MAc). These surfactant mixtures have several advantages in comparison to other foam sta bilizers that have been used for control of surface mobility so far: a wide range of surface properties is possible by varying surfactant composition, variable bulk viscosity with Newtonian behaviour of the liquid phase, clear solutions without precipitates and no grad ual changes of surface properties with time (typical for proteins).

Rouimi et al (2005) in their study on foam stability and interfa cial properties of milk protein surfactant systems found that whatever the protein type, the interface is elastic rather than vis cous. For one type of interface (air water interface or oil water interface) no matter what protein in present, the surface tension values are quite similar. Therefore, protein samples cannot be sig nificantly differentiated from each other based on surface tension values. However, these values are of importance in differentiating proteins from surfactants (Rouimi et al., 2005). Milk proteins satu rate fluid interfaces at much lower concentrations than do small molecular weight surfactants (Dickinson, 2001). Competitive adsorption of pure milk proteins ( $\beta$ casein or $\beta$ lactoglobulin) with non ionic surfactants in oil in water emulsions is shown to depend on the age of the adsorbed protein layer (Chen et al., 1993). It was found that water soluble surfactants are more effective than oil soluble surfactants in displacing protein molecules from interfaces (Dickinson, 2001; Rouimi et al., 2005).

Adler et al. (2000) studied how the addition of a surfactant re duces protein adsorption in a mixture of trehalose, BSA and surfac tant during spray drying. In this study, three surfactants (polysorbate 80 , sodium dodecyl sulphate (SDS) and phospholipid lipoid (E80) were tried. At low surfactant concentration the protein components predominates at the interface for a mixed solution of proteins and surfactants. Whereas at high surfactant concentra 
tions, a lower interfacial tension for surfactants than for proteins was observed due to more efficient packing in the saturated mono layer. Thereby the protein is completely displaced from the inter face (Dickinson, 2001; Adler et al., 2000). It was found that no surfactant was capable of fully covering the surface at the point of complete protein exclusion. Protein exclusion from the water air interface could be due to the complex formation between pro tein and surfactant in the bulk spray solution prior to atomization (Adler et al., 2000). The transition between predominantly protein and predominantly surfactant stabilized emulsions is gradual and involves two major effects. Firstly the surfactant binds to the pro tein molecules, which occurs to a much larger extent for ionic sur factants compared to non ionic surfactants (Dickinson and Woskett, 1989; Stenstam et al., 2001). Secondly, the surfactant ad sorbs to the interface and at a sufficiently large concentration, competes with the protein for the available area (De Feijter et al., 1987; Dickinson and Woskett, 1989; Courthaudon et al., 1991; Chen and Dickinson, 1993; Horne et al., 1998). An important parameter here is the molar ratio $(R)$ of surfactant and protein present in the system. A gradual displacement of protein by non ionic surfactants occurred in the range $1<R<20$ in emulsions (van Aken, 2003). Coke et al. (1990) observed that at low $R$, an adsorbed protein layer stabilized the emulsion, whereas at high, $R$ the stability was obtained from an adsorbed surfactant layer. Neither mechanism was effective in explaining the relative insta bility of emulsion for intermediate $R$. $\beta$ lactoglobulin was able to bind one uncharged lipid or surfactant molecule per protein mole cule. At $R<1$ most Tween 20 was bound to $\beta$ lactoglobulin, while at $R>1$ free surfactant remained in the solution and was able to dis place adsorbed protein molecules by forming a surfactant layer (van Aken, 2003). The relative molar ratio of surfactant: protein necessary for complete displacement of protein is higher for SDS than for polysorbate 80 (Adler et al., 2000). van Aken (2003) also suggested that one of the functions of adding surfactants to emul sions, which are primarily stabilized by protein, was to reduce the sensitivity to flow induced coalescence. The adsorption behaviour of $\beta$ lactoglobulin showed substantial time dependence.

Wilde and Clark (1993) studied the displacement of $\beta$ lacto globulin by Tween 20 from oil water and air water interfaces and showed that the disruption of protein protein interactions and the onset of protein surface diffusion occurred at much lower molar ratios in the oil water oil film compared to the air water air film. This was due to the increased surface activity of $\beta$ lacto globulin: Tween 20 complex at the oil water interface (Wilde and Clark, 1993). De Feijter et al. (1987) studied the displacement of proteins ( $\beta$ casein and $\beta$ lactoglobulin) by water and oil soluble surfactants in $50 \%$ oil in water emulsions. The surface concentra tion of both protein and surfactant was measured. It was found that the surfactants partly or even completely displaced the pro tein from the droplet surface, depending on the surfactant concen tration and type. The displacement was found to be independent of protein type and the way in which the surfactant was added (be fore or after emulsification) but was found, to some extent, to de pend on the type of oil (De Feijter et al., 1987).

Cornec et al. (1998) found that an interface stabilized by $\beta$ case in was more sensitive to oil soluble surfactant concentrations than one stabilized by $\beta$ lactoglobulin. This was probably due to the for mation of more viscoelastic interface by $\beta$ lactoglobulin compared to $\beta$ casein (Murray and Dickinson, 1996). However, water soluble surfactants are more effective than oil soluble surfactants in dis placing protein molecules from interfaces of various commercial products separately or in mixtures (Dickinson, 2001; Rouimi et al., 2005). A much higher surfactant concentration is needed for complete displacement of protein for an anionic surfactant such as SDS, which forms interfacial complexes with protein (Dickinson, 2001). By knowing the balance of protein protein, protein surfac tant and surfactant surfactant, both at the interface and the bulk solution, the detailed structure and composition of the mixed pro tein and surfactant layer could be determined (Dickinson, 2001). The molecular hydrophilic lipophilic balance (HLB) determines whether a surfactant is predominantly oil soluble (low HLB) or water soluble (high HLB) (Cornec et al., 1998). High stability of oil water emulsion is obtained for surfactants with a high HLB number (van Aken, 2003). Molecules of water soluble surfactants have the ability to bind to protein molecules both by electrostatic interaction (if the surfactant is ionic) and by hydrophobic interac tion involving their hydrophobic tails and hydrophobic groups of the protein. If the HLB is larger for a protein surfactant complex than for a protein molecule on its own, a solubilization mechanism will make it easier for the displacement of some of the protein from the monolayer of the interface (Pugnaloni et al., 2004).

Proteins do denature when exposed to an air/water interface since proteins are frequently unfolded there. The potential for sur face induced denaturation is substantial in particular at a low pro tein load when the large surface area in a spray is considered (Mumenthaler et al., 1994; Maa et al., 1998; Millqvist Fureby et al., 1999). Addition of a polymeric coating to protein formula tions during spray drying could enhance the protein stability by preventing or reducing protein surface interactions. Prevention/ reduction of protein surface interactions can be observed for pro tein formulations with addition of LMS such as polysorbate 20, polysorbate 80 and SDS etc (Maa et al., 1998; Mumenthaler et al. 1994; Millqvist Fureby et al., 1999; Adler et al., 2000).

In pharmaceutical science the competitive adsorption of pro teins and LMS has been extensively researched (Maa et al., 1998; Maa and Hsu, 1997). It is very important that the protein denatur ation is prevented or reduced. Polysorbate being a low molecular weight surfactant occupies the air liquid interface of spray drop lets, thereby reducing the chance for active protein ingredients to form insoluble aggregates by surface denaturation. The minimum polysorbate concentration, which gave the best protection from aggregation, is said to be the critical polysorbate concentration (cpc). Excess polysorbate molecules have no effect on further pre venting protein molecules from aggregation beyond the cpc. The cpc was found to be around $0.05 \%$ regardless of protein concentra tions (Maa et al., 1998).

The surface activity of different components has shown to have a strong impact on protein surface coverage (Abdul Fattah et al., 2007; Vehring, 2008). The effect of addition of Polysorbate 80 (Tween 80) and SDS on the spray drying of protein sugar solution was studied by Adhikari et al. (2007b). A trace amount of surfac tants was added $(0.05 \% \mathrm{w} / \mathrm{w})$ in the sample. It was observed that when merely $0.05 \%$ of Tween 80 was added to both the sucrose sodium caseinate (99.5:0.5) and sucrose whey protein isolate (99.5:0.5) solutions, no powders were obtained. No difference in recovery was observed even in the presence of a higher amount of proteins (sucrose: sodium caseinate = sucrose: whey protein iso late $=99: 1$ ) or the use of different types of proteins. These results show that Tween 80 had displaced protein completely from the droplet surface indicating that it is not the right choice for amor phous powder production from sugar rich foods (Adhikari et al., 2007b). A similar study was carried out by Grigoriev et al (2007), based on the structure and rheological properties of mixed BSA/ Tween 80 adsorption layers at the air/water interface. The incorpo ration of increasing amounts of Tween 80 into adsorption layer very efficiently destroys its network structure which exists be tween BSA molecules at $C_{\text {Tween-80 }}=10^{-6} \mathrm{M}$ and below. The whole BSA is displaced into the subsurface and the network structure be comes completely broken at $C_{\text {Tween-80 }}=5 \times 10^{-6} \mathrm{M}$ (Grigoriev et al., 2007). On the other hand when $0.05 \%$ of SDS was added to sucrose sodium caseinate (99.5:0.5) solution the powder recovery was $64 \%$, which is $21 \%$ less, compared to the recovery from the same solu 
tion in the absence of SDS. Similarly when the same amount of SDS was added to sucrose whey protein isolate (99.5:0.5) solution the powder recovery was $39 \%$. However with a higher amount of pro tein (sucrose sodium caseinate $=$ sucrose: whey protein isolate $=99: 1$ ) the total recovery increased to $68 \%$ in the case of sucrose sodium caseinate and in the case of sucrose: whey protein isolate the powder recovery increased to $63 \%$. Where powder recovery is concerned the effect of SDS on the effectiveness of these two pro teins is almost similar when they were present at concentrations greater than $0.25 \%$ in the solution. However at lower concentra tions $(0.125 \%)$ whey protein isolate showed much less effective ness in reducing stickiness on powder recovery (Adhikari et al., 2007b). The difference in effectiveness of Tween 80 and SDS in dis lodging the protein from the droplet surface could be due to their inherently different surfactant protein interactions, which can be explained by the Orogenic displacement model (Mackie et al., 1999). In the Orogenic displacement model, the surfactant mole cules adsorb at vacant defects or holes in the protein network. These nucleated sites grow, compressing the protein network. At the initial stage the compression of the protein network occurs without displacement of the proteins from the interface. At the second stage the buckling of the monolayer and reordering of the molecules occur as the protein film gets thicker with regard to the decreasing surface coverage. Finally the protein network begins to fail at sufficiently high surface pressures and thereby freeing the proteins, which then desorbs from the interface. Bezelgues et al. (2008) compared the foaming and foam stabilization performance of low molecular weight food grade lamellar crystal forming sur factants (SSL, Datem and Cremodan Super) with those of a micelle forming surfactant (Tween 80) and WPI. Foams produced by SSL, Datem and Cremodan Super were more stable than the foams generated in the presence of WPI or Tween 80. Moreover, SSL, Datem and Cremodan showed lower equilibrium surface tension compared to those of Tween 80 and WPI. This observation indicates that once lamellar crystal forming surfactants are at the interface they form tightly packed surfactants layers around the foam bubbles with sufficiently high viscoelastic properties.

\section{Concluding remarks}

A rich amount of information is available on the composition and structure of interfacial layers consisting of proteins and surfac tants and how these interfacial layers stabilise emulsions and spray dried milk powders. Furthermore, a large pool of informa tion is available regarding the surface and bulk composition of spray dried powders. However, very little information is available on how surface migration is quantified for spray dried powders containing sugars and organic acids when proteins are added as 'smart drying aids'. The effect of food grade surfactants on particle formation process of sugar protein water system is not yet ex plored. Since spray drying of sugar and acid rich foods is a major challenge to both academia and industry due to their inherent sticky behaviour, surface modification by proteins along with LMS can be very useful in overcoming this problem. In this regard it is very important that surface migration of proteins and LMS is quantified and the mechanisms of surfactant protein sugar inter actions during drying process are studied. Information coming from such studies can be applied to produce composite and surface engineered food powders through spray drying.

In this regard, research is underway in our laboratory to quan tify the migration of protein in sugar protein matrix, and migra tion of food grade surfactant in sugar protein surfactant matrix, and their implication in powder formation of sugar and acid rich foods.

\section{References}

Abdul-Fattah, A.M., Kalonia, D.S., Pikal, M.J., 2007. The challenge of drying method selection for protein pharmaceuticals: Product quality implications. Journal of Pharmaceutical Sciences 96 (8), 1886-1916.

Adhikari, B., Howes, T., Shrestha, A.K., Bhandari, B.R., 2007a. Development of stickiness of whey protein isolate and lactose droplets during convective drying. Chemical Engineering and Processing 46, 420-428.

Adhikari, B., Howes, T., Shrestha, A., Bhandari, B.R., 2007b. Effect of surface tension and viscosity on the surface stickiness of carbohydrate and protein solutions. Journal of Food Engineering 79 (4), 1136-1143.

Adhikari, B., Howes, T., Bhandari, B.R., Langrish, T.A.G., 2009a. Effect of addition of proteins on the production of amorphous sucrose powder through spray drying. Journal of Food Engineering, in press, doi:10.1016/j.jfoodeng.2009.01.029.

Adhikari, B., Howes, T., Wood, B.J., Bhandari, B.R., 2009b. The effect of low molecular weight surfactants and proteins on surface stickiness of sucrose during powder formation through spray drying. Journal of Food Engineering, in press, doi:10.1016/j.jfoodeng.2009.01.022.

Adler, M., Unger, M., Lee, G., 2000. Surface composition of spray-dried particles of BSA/trehalose and surfactant. Pharmaceutical Research 17 (7), 863-870.

Alexander, K., King, C.J., 1985. Factors governing surface morphology of spray-dried amorphous substances. Drying Technology 3, 321-348.

Audu, T.O.K., Loncin, M., Weisser, H., 1978. Sorption isotherms of sugars. Lebensmittel-Wissenschaft and Technologie 11 (2), 31-34

Baranauskienè, R., Venskutonis, P.R., Dewettinck, K., Verhé, R., 2006. Properties of oregano (Origanum vulgare L.), citronella (Cymbopogon nardus G.) and marjoram (Majorana hortensis L.) flavours encapsulated into milk protein based matrices. Food Research International 39 (4), 413-425.

Barbosa, M.I.M.J., Borsarelli, C.D., Mercadante, A.Z., 2005. Light stability of spraydried bixin encapsulated with different edible polysaccharide preparations. Food Research International 38 (8-9), 989-994

Beristain, C.I., Garcia, H.S., Vernon-Carter, E.J., 2001. Spray-dried encapsulation of cardamom (Elettaria cardamom) essential oil with mesquite (Prosopis juliflora) gum. Lebensmittel-Wissenschaft und-Technologie 34, 398-401.

Berlin, E., Pallansch, M.J., 1968. Densities of several proteins and L-amino acids in the dry state. The Journal of Physical Chemistry 72 (6), 1887-1889.

Bezelgues, J.B., Serieye, S., Crosset-Perrotin, L., Leser, M.E., 2008. Interfacial and foaming properties of some food grade low molecular weight surfactants. Colloids and Surfaces A: Physicochemical and Engineering Aspects. doi:10.1016/j.colsurfa.2008.07.022.

Bhandari, B.R., Senoussi, A., Dumoulin, E.D., Lebert, A., 1993. Spray drying of concentrated fruit juices. Drying Technology 11 (5), 1081-1092.

Bhandari, B.R., Datta, N., Howes, T., 1997. Problems associated with spray drying of sugar-rich foods. Drying Technology 15 (2), 671-684.

Bhandhari, B., Howes, T., 2004. Relating the stickiness property of foods undergoing drying and dried products to their surface energetics. Drying Technology 23, 781-797.

Boonyai, P., 2005. Development of new instrumental techniques for measurement of stickiness of solid particulate food materials. PhD thesis, The University of Queensland.

Brun, J.M., Dalgleish, D.G., 1999. Some effects of heat on the competitive adsorption of caseins and whey proteins in oil-in-water emulsions. International Dairy Journal 9, 323-327.

Bylaite, E., Venskutonis, P.R., Mapdbieriene, R., 2001. Properties of caraway (Carum carvi L.) essential oil encapsulated into milk protein-based matrices. European Food Research and Technology 212, 661-670.

Chen, J.S., Dickinson, E., 1993. Time-dependant competitive adsorption of milk proteins and surfactants in oil-in-water emulsions. Journal of Science Food Agriculture 62 (3), 283-289.

Chen, J., Dickinson, E., Iveson, G., 1993. Interfacial interactions, competitive adsorption and emulsion stability. Food Structure 2, 135-146.

Clark, D.C., Coke, M., Mackie, A.R., Pinder, A.C., Wilson, B., 1990. Molecular diffusion and thickness measurements of protein-stabilized thin liquid films. Journal of Colloid and Interface Science 138, 207-219.

Coke, M., Wilde, P.J., Russel, E.J., Clark, D.C., 1990. The influence of surface composition and molecular diffusion on the stability of foams formed from protein/surfactant mixtures. Journal of Colloid and Interface Science 138 (2), 489-504.

Cornec, M., Wilde, P.J., Gunning, P.A., Mackie, A.R., Husband, F.A., Parker, M.L., Clark, D.C., 1998. Emulsion stability as affected by competitive adsorption between an oil-soluble emulsifier and milk proteins at the interface. Journal of Food Science 63 (1), 39-43.

Couchman, P.R., Karaz, F.E., 1978. A classical thermodynamic discussion of the effect of composition on glass-transition temperature. Macromolecules 11 (1), 177188 .

Courthaudon, J.L., Dickinson, E., Dalgleish, D.G., 1991. Competitive adsorption of $\beta$ casein and non-ionic surfactants in oil-in-water emulsions. Journal of Colloid and Interface Science 145, 390-395.

Dalgleish, D.G., 1996. Conformations and structures of milk proteins adsorbed to oil-water interfaces. Food Research International 29 (5-6), 541-547.

Dalgleish, D.G., 1997. Adsorption of protein and stability of emulsions. Trends in Food Science and Technology 8, 1-8.

Dalgleish, D.G., 2006. Food emulsions-their structures and structure-forming properties. Food Hydrocolloids 20, 415-422. 
De Feijter, J.A., Benjamins, J., Tamboer, M., 1987. Adsorption displacement of proteins by surfactants in oil-in-water emulsions. Colloids and Surfaces 27, 243-266.

Deman, J.M., 1976. Principles of Food Chemistry (p. 145), AVI Publishing Company Westport, Connecticut, USA.

Dickinson, E., 1994. Protein-stabilized emulsions. Journal of Food Engineering 22 $59-74$.

Dickinson, E., 2001. Review: milk protein interfacial layers and the relationship to emulsion stability and rheology. Colloids and Surfaces B: Biointerfaces 20, 197 210.

Dickinson, E., Rolfe, S.E., Dalgleish, D.G., 1988. Competitive adsorption of $\alpha_{\mathrm{s} 1}$-casein and $\beta$-casein in oil-in-water emulsions. Food Hydrocolloids 2, 397-405.

Dickinson, E., Radford, S.J., Golding, M., 2003. Stability and rheology of emulsion containing sodium caseinate: combined effects of ionic calcium and non-ionic surfactant. Food Hydrocolloids 17, 211-220.

Dickinson, E., \& Woskett, C. M. (1989). Competitive adsorption between proteins and small-molecule surfactants in food emulsions. Food Colloids. In The Proceedings of Royal Society of Chemistry, London, UK. Bee, R.D., Richmond, P., \& Mingins, J. (Editors).74-96.

Dimitrova, T.D., Leal-Calderon, F., Gurkov, T.D., Cambell, B., 2004. Surface forces in model oil-in-water emulsions stabilized by proteins. Advances in Colloid and Interface Science 108-109, 73-86.

Downton, G.E., Flores-Luna, J.L., King, C.J., 1982. Mechanisms of stickiness in hygroscopic, amorphous powders. Industrial \& Engineering Chemistry Fundamentals 21 (4), 447-451.

Drusch, S. (2006). Sugar beet pectin: a novel emulsifying wall component for microencapsulation of lipophilic food ingredients by spray-drying. Food Hydrocolloids, doi:10.1016/j.foodhyd.2006.08.007.

Drusch, S., Serfert, Y., Van Den Heuvel, A., Schwarz, K., 2006. Physicochemical characterization and oxidative stability of fish oil encapsulated in an amorphous matrix containing trehalose. Food Research International 39, 807815.

Elversson, J., Millqvist-Fureby, A., 2005. Aqueous two-phase systems as a formulation concept for spray-dried protein. International Journal of Pharmaceutics 294, 73-87.

Elversson, J., Millqvist-Fureby, A., 2006. In situ coating - An approach for particle modification and encapsulation of proteins during spray-drying. International Journal of Pharmaceutics 323, 52-63.

Fainerman, V.B., Miller, R., Ferri, J.K., Watzke, H., Leser, M.E., Michel, M., 2006. Reversibility and irreversibility of adsorption of surfactants and proteins at liquid interfaces. Advances in Colloid and Interface Science 123, 163-171.

Fäldt, P., Bergenståhl, B., Carlsson, G., 1993. The surface coverage of fat on food powders analysed by ESCA (Electron Spectroscopy for Chemical Analysis). Food Structure 12, 225-234.

Fäldt, P., Bergenståhl, B., 1994. The surface composition of spray-dried proteinlactose powders. Colloids and Surfaces A: Physicochemical and Engineering Aspects 90, 183-190.

Fäldt, P., Bergenståhl, B., 1995. Fat Encapsulation in spray dried powders. JAOCS 72 (2), 171-176.

Fäldt, P., 1995. PhD thesis, Department of Food Engineering. Lund University, Lund, Sweden.

Fäldt, P., Bergenståhl, B., 1996. Spray-dried whey protein/lactose/soybean oil emulsions.2. Redispersibility, wettability and particle structure. Food Hydrocolloids 10 (4), 431-439.

Fang, Y., Dalgleish, D.G., 1993. Dimensions of the adsoebed layers in oil-in-water emulsions stabilized by caseins. Journal of Colloid and Interface Science 156 329-334.

Fang, Y., Dalgleish, D.G., 1998. The conformation of $\beta$-lactoglobulin studied by FTIR: effect of $\mathrm{pH}$, temperature and hydrophobic surfaces. Journal of Colloid and Interface Science 196, 292-298.

Freer, E.M., Yim, K.S., Fuller, G.G., Radke, C.J., 2004. Shear and dilatational relaxation mechanisms of globular and flexible proteins at the hexadecane/wate interface. Langmuir 20 (23), 10159-10167.

Gaiani, C., Ehrhardt, J.J., Scher, J., Hardy, J., Desobry, S., Banon, S., 2006. Surface composition of dairy powders observed by X-ray photoelectron spectroscopy and effects on their rehydration properties. Colloids and Surfaces B: Biointerfaces 49, 71-78.

Golemanov, K., Denkov, N.D., Tcholakova, S., Vethamuthu, M., Lips, A., 2008. Surfactant mixtures for control of bubble surface mobility in foam studies. Langmuir 24, 9956-9961.

Grigoriev, D.O., Derkatch, S., Krägel, J., Miller, R., 2007. Relationship between structure and rheological properties of mixed BSA/Tween 80 adsorption layers in the air/water interface. Food Hydrocolloids 21, 823-830.

Hogan, S.A., McNamee, N.F., O'Riordan, E.D., O'Sullivan, M., 2001. Emulsification and micro-encapsulation properties of sodium caseinate /carbohydrate blends. International Dairy Journal 11, 137-144.

Horne, D.S., Atkinson, P.J., Dickinson, E., Pinfield, V.J., Richardson, R.M., 1998 Neutron reflectivity study of competitive adsorption of $\beta$-lactoglobulin and non-ionic surfactant at the air-water interface. International Dairy Journal 8 73-77.

Hunt, J.A., Dalgleish, D.G., 1994a. Adsorption behaviour of whey protein isolate and caseinate in soya oil-in-water emulsions. Food Hydrocolloids 8, 175-187.

Hunt, J.A., Dalgleish, D.G., 1994b. The effect of pH on the stability and surface composition of emulsions made with whey protein isolate. Journal of Agricultural and Food Chemistry 42, 2131-2135.
Jones, D.B., Middelberg, A.P.J., 2003. Interfacial protein networks and their impact on droplet break-up. AIChE Journal 49 (6), 1533-1541.

Kelley, F.H.C., Mak, F.K., Shah, D., 1974. Some hygroscopic properties of refined sugar. International Sugar Journal 76 (912), 361-363.

Kim, E.H.J., Chen, X.D., Pearce, D., 2002. Surface characterization of four industria spray-dried dairy powders in relation to chemical composition, structure and wetting property. Colloids and Surfaces B: Biointerfaces 26, 197212

Kim, E.H.J., Chen, X.D., Pearce, D., 2003. On the mechanisms of surface formation and the surface composition of industrial powders. Drying Technology 21 (2), $265-278$

Krishnan, S., Kshirsagar, A.C., Singhal, R.S., 2005. The use of gum arabic and modified starch in the micro-encapsulation of a good flavouring agent. Carbohydrate Polymers 62, 309-315.

Labuza, T.P., 1995. Properties of sorption isotherms of foods, in water activity theory, management and application. Course Workbook. University of Queensland. Department of Food Science and Technology Gatton College and Shanaglen Technology, Brisbane, Australia, August 21-24, 1995.

Landström, K., Bergenståhl, B., Alsins, J., Almgren, M., 1999. Fluorescence method for quantitative measurements of specific protein at powder surfaces. Colloids and surfaces B: Biointerfaces 12, 429-440.

Landström, K., Alsins, J., Bergenståhl, B., 2000. Competitive protein adsorption between bovine serum albumin and $\beta$-lactoglobulin during spray-drying. Food Hydrocolloids $14,75-82$.

Lucassen-Renders, E.H., Fainerman, V.B., Miller, R., 2004. Surface dilational modulus or gibbs' elasticity of protein adsorption layers. Journal of Physical Chemistry B 108 (26), 9173-9176.

Maa, Y.F., Hsu, C.C., 1997. Protein denaturation by combined effect of shear and airliquid interface. Biotechnology and Bioengineering 54 (6), 503-512.

Maa, Y.F., Nguyen, P.A.T., Hsu, S.W., 1998. Spray drying of air-liquid interface sensitive recombinant human growth hormone. Journal of Pharmaceutical Sciences 87 (2), 152-159.

Mackie, A.R., Gunning, P.A., Wilde, P.J., Morris, V.J., 1999. Orogenic displacement of protein from the air/water interface by competitive adsorption. Journal of Colloid and Interface Science 210, 157-166.

Mackie, A. R., Gunning, P. A., Wilde, P. J., \& Morris, V. J. (2000). Competitive displacement of Beta-lactoglobulin from the air/water interface by sodium dodecyl sulphate. Langmuir, 16(21), 8176-8181.

Mackie, A., Wilde, P., 2005. The role of interactions in defining the structure of mixed protein-surfactant interfaces. Advances in Colloid and Interface Science $117(1-3), 3-13$

MacRitchie, F., \& Alexander, A. E. (1963a). Kinetics of adsorption of proteins at interfaces. Part 1.The role of bulk diffusion in adsorption. Journal of Colloid Science, 18, 453-457.

MacRitchie, F., \& Alexander, A. E. (1963b). Kinetics of adsorption of proteins at interfaces. Part 11.The role of pressure barriers in adsorption. Journal of Colloid Science, 18, 458-463.

MacRitchie, F., \& Alexander, A. E. (1963c). Kinetics of adsorption of proteins at interfaces. Part 111.The role of electrical barriers in adsorption. Journal of Colloid Science, 18, 464-469.

Maldonado-Valderrama, J., Fainerman, V.B., Gálvez-Ruiz, M.J., Marín-Rodriguez, A., Cabrerizo-Vílchez, M.A., Miller, R., 2005. Dilatational rheology of $\beta$-casein adsorbed layers at liquid-fluid interfaces. Journal of Physical Chemistry B 109 (37), 17608-17616.

Millqvist-Fureby, A., Burns, N., Landström, K., Fäldt, P., \& Bergenståhl, B. (1999). Surface activity at the air-water interface in relation to surface composition of spray-dried milk protein-stabilized emulsions. In Food Emulsions and Foams (236-345). Royal Society of Chemistry.

Millqvist-Fureby, A., Malmsten, M., Bergenståhl, B., 1999b. Spray drying of trypsinsurface characterization and activity preservation. International Journal of Pharmaceutics 188, 243-253.

Millqvist-Fureby, A., Elofsson, U., Bergenståhl, B., 2001. Surface composition of spray-dried milk protein-stabilised emulsions in relation to pre-heat treatment of proteins. Colloids and surfaces B: Biointerfaces 21 (1-3), 47-58.

Mumenthaler, M., Hsu, C.C., Pearlman, R., 1994. Feasibility study on spray drying protein pharmaceuticals: recombinant human growth hormone and tissue type plasminogen activator. Pharmaceutical Research 11, 12-20.

Murray, B.S., Dickinson, E., 1996. Interfacial rheology and the dynamic properties of adsorbed films of food proteins and surfactants. Food Science and Technology 2 $131-145$.

Murray, B.S., Ventura, A., Lallemant, C., 1998. Dilatational rheology of protein + nononic surfactant films at air-water and oil-water interfaces. Colloids and Surfaces $143,211-219$.

Nijdam, J.J., Langrish, T.A.G., 2006. The effect of surface composition on the functional properties of milk powders. Journal of Food Engineering 77, 919925.

Oneda, F. Ré, M.L. 2003. The effect of formulation variables on the dissolution and physical properties of spray-dried micro-spheres containing organic salts. Powder Technology 130, 377-384.

Perry, R.H., Green, D.W., Maloney, J.O., 1973, fifth ed. Perry's Chemical Engineers' Handbook McGraw-Hill Book Company. pp. 3-38.

Pugnaloni, L.A., Dickinson, E., Ettelaie, R., Mackie, A.R., Wilde, P.J., 2004. Competitive adsorption of proteins and low molecular-weight surfactants: compute simulation and microscopic imaging. Advances in Colloid and Interface Science $107,27-49$ 
Rigby, S., Bhandari, B.R., Howes, T., 1996. Semi-empirical approach to optimize the quantity of drying aid required to spray-dry honey. In: Programme and Abstract Book, 29th Annual Convention of AIFST, 5-8 May, Gold Coast, Australia.

Rodríguez Patino, J.M., Rodríguez Niño, M.R., Carrera, C., 2003. Protein-emulsifier interactions at the air-water interface. Current Opinion Colloid Interface Science 8, 387-395.

Rodríguez Niño, M.R., Sánchez, C.C., Ruíz-Henestrosa, V.P., Rodríguez Patino, J.M., 2005. Milk and soy protein films at the air-water interface. Food Hydrocolloids 19, 417-428

Romoscanu, A.I., Mezzenga, R., 2005. Cross linking and rheological characterization of adsorbed protein layers at the oil-water interface. Langmuir 21 (21), 96899697.

Roos, Y., Karel, M., 1991. Water and molecular weight effects on glass transitions in amorphous carbohydrates and carbohydrate solutions. Journal of Food Science $56,1676-1681$.

Rosenberg, M., Sheu, T.Y., 1996. Micro-encapsulation of volatiles by spray-drying in whey protein-based wall systems. International Dairy Journal 6, 273-284.

Rouimi, S., Schorsch, C., Valentini, C., Vaslin, S., 2005. Foam Stability and interfacial properties of milk protein-surfactant systems. Food Colloids 19, 467-478.

Sánchez, C.C., Rodríguez Patino, J.M., 2005. Interfacial foaming and emulsifying characteristics of sodium caseinate as influenced by protein concentration in solution. Food Hydrocolloids 19 (3), 407-416.

Shaikh, J., Bhosale, R., \& Singhal, R. (2006).Micro-encapsulation of black pepper oleoresin. Food Chemistry, 94, 105-110.

Shrestha, A.K., Howes, T., Adhikari, B.P., Wood, B.J., Bhandari, B.R., 2007a. Effect of protein concentration on the surface composition, water sorption and glass transition temperature of spray-dried skim milk powders. Food Chemistry 104, $1436-1444$.

Shrestha, A. K., Ua-arak, T., Adhikari, B. P., Howes, T., \& Bhandari, B. R. (2007). Glass transition behaviour of spray dried orange juice powder measured by differential scanning calorimetry (DSC) and thermal mechanical compression test (TMCT).

Shu, B., Yu, W., Zhao, Y., Liu, X., 2006. Study on the micro-encapsulation of lycopene by spray-drying. Journal of Food Engineering 76, 664-669.

Sliwinski, E.L. Lavrijsen, B.W.M. Vollenbroek, J.M., van der Stege, H.J., van Boekel, M.A.J.S., Wouters, J.T.M., 2003. Effects of spray drying on Physicochemical properties of milk protein-stabilized emulsions. Colloids and Surfaces B: Biointerfaces 31, 219-229.

Srinivasan, M., Singh, H., Munro, P.A., 1996. Soduim caseinate-stabilized emulsions: factors affecting coverage and composition pf surface proteins. Journal of Agricultural and Food Chemistry 44, 3807-3811.

Stenstam, A., Khan, A., Wennerström, H., 2001. The lysozyme-dodecyl sulphate system. An example of protein-surfactant aggregation. Langmuir 17, 75137520.

Soottitantawat, A., Bigeard, F., Ohkawara, M., Linko, P., 2005a. Influence of emulsion and powder size on the stability of encapsulated D-limonene by spray drying. Innovative Food Science and Emerging Technologies 6, 107-114.

Soottitantawat, A., Takayama, K., Okamura, K., Muranaka, D., Yoshii, H., Furuta, T., 2005b. Micro-encapsulation of L-menthol by spray drying and its release characteristics. Innovative Food Science and Emerging Technologies 6, 163-170.

Tcholakova, S., Denkov, N.D., Ivanov, I.B., Campbell, B., 2002. Coalescence in $\beta$ lactoglobulin-stabilized emulsions: effects of protein adsorption and drop size. Langmuir 18, 8960-8971.
Tcholakova, S., Denkov, N.D., Ivanov, I.B., Campbell, B., 2006a. Coalescence stability of emulsions containing globular milk proteins. Advances in Colloid and Interface Science 123-126, 259-293.

Tcholakova, S., Denkov, N.D., Sidzhakova, D., Campbell, B., 2006b. Effect of thermal treatment, ionic strength, and $\mathrm{pH}$ on the short-term and long-term coalescence stability of $\beta$-lactoglobulin emulsions. Langmuir 22, 6042-6052.

Teixeira, M. I. Andrade, L.R. Farina, M. \& Rocha-Leão, M. H. M. (2004). Characterization of short chain fatty acid microcapsules produced by spray drying. Material Science and Engineering, 24, 653-658.

Truong, V., Bhandari, B.R., Howes, T., 2005. Optimization of concurrent spray drying process for sugar-rich foods. Part 11-Optimization of spray drying process based on glass transition concept. Journal of Food Engineering 71 (1) 66-72.

van Aken, G.A., 2003. Competitive adsorption of protein and surfactants in highly concentrated emulsions: effect of coalescence mechanisms. Colloids and Surfaces A: Physicochemical and Engineering Aspects 213, 209-219.

Vega, C., Goff, H.D., Roos, Y.H., 2005a. Spray drying of high-sucrose dairy emulsions: feasibility and physicochemical properties. Journal of Food Science 70 (3), 244251

Vega, C., Kim, E.H.J., Chen, X.D., Roos, Y.H., 2005b. Solid state characterization of spray-dried ice cream mixes. Colloids and Surfaces B: Biointerfaces 45, 66-75.

Vega, C. Roos, Y.H., 2006. Invited review: spray-dried dairy and dairy-like emulsions-compositional changes. Journal of Dairy Science 89, 383-401.

Vehring, R., 2008. Pharmaceutical particle engineering via spray drying. Pharmaceutical Research 25 (5), 999-1022.

Vignolles, M.L., Jeantet, R., Lopez, C., Schuck, P., 2007. Free fat, surface fat and dairy powders: interactions between process and product. A review. Lait 87 (3), 187236.

Wallack, D.A., King, C.J., 1988. Sticking and agglomeration of hygroscopic, amorphous carbohydrate and food powders. Biotechnology Progress 4 (1), 31-35.

Watanabe, Y., Fang, X., Adachi, S., Fukami, H., Matsuno, R., 2004. Oxidation of 6-0arachidonoyl-ascorbate microencapsulated with a polysaccharide by spraydrying. Lebesmittel-Wissenschaft und-Technologie 37, 395-400.

Weast, R.C., Astle, M.J., 1979. Physical constants of organic compounds. In: CRC Handbook of Chemistry and Physics, 59th Edition. CRC press, Florida.

Wilde, P.J., Clark, D.C., 1993. The competitive displacement of $\beta$-lactoglobulin by Tween 20 from oil-water and air-water interfaces. Journal of Colloid and Interface Science 155, 48-55.

Wilde, P., Mackie, A., Husband, F., Gunning, P., Morris, V., 2004. Proteins and emulsifiers at liquid interfaces. Advances in Colloid and Interface Science 266 (1), 195-201.

Williams, A., Prins, A., 1996. Comparison of the dilatational behaviour of adsorbed milk proteins at the air-water and oil-water interfaces. Colloids and Surfaces APhysicochemical and Engineering Aspects 114, 267-275.

Xu, R., Dickinson, E., Murray, B.S., 2008. Morphological changes in adsorbed protein films at the oil-water interface subjected to compression, expansion, and heat processing. Langmuir 24 (5), 1979-1988.

Ye, A., 2008. Interfacial composition and stability of emulsions made with mixtures of commercial sodium caseinate and whey protein concentrate. Food Chemistry 110 (4), 946-952.

Young, S.L., Sarda, X., Rosenberg, M., 1993. Micro-encapsulation properties of whey proteins. 1. Micro-encapsulation of anhydrous milk fat. Journal of Dairy Science (76), 2868-2877. 